\title{
Study on the Promotion Strategy of National Cultural Soft Power
}

\author{
Meng Su ${ }^{1}$ \\ ${ }^{1}$ Oxbridge College, Kunming University of Science and Technology, Kunming, Yunnan, 650106
}

\section{KEYWORDS: National Cultural Soft Power; Promotion Strategy; International Competitiveness}

\begin{abstract}
Cultural soft power is the comprehensive national strength and international competitiveness of the important part. On Formation of Chinese and foreign cultural soft power, savings and development trend, it has the inheritance, cohesion, sustainability and creative features. Compared with developed countries, China to enhance cultural soft power has lead the advantages of the socialist core value system, the advantages of the international image of China's peaceful development, development and prosperity of socialist culture protection advantage. Grasp the characteristics, advantages, our country to enhance the cultural soft power strategy: the development of cultural industry cluster, the combined effect of activating cultural industries; expand cultural product consumption, expand cultural productivity development; development of cultural innovation plan, build national cultural innovation system; committed high culture products go out to enhance the affinity of the international image of the country.
\end{abstract}

\section{Introduction}

Cultural soft power is a hybrid concept, the first is "culture" and "soft power" more "cultural soft power." Therefore, cultural soft power to make a more accurate, profound and comprehensive understanding, must first "culture" and "soft power" to make defined. Cultural theorists currently define our culture and there are two main views, one big cultural view, emphasizing the cultural and social practices related to people. Another view is from the more narrowly defined the level of culture and culture is considered "part of the concept of social structure. It is composed of specific symbols (language and other symbol) to convey, a variety of ideas in practice created by human, social life and norms of behavior of the sum. "? Western scholars definition of" culture "and more about the symbols that refers specifically to human culture and nature are closely related to lifestyle, human understanding, perception of nature and people's own symbol, but also social results of practice. As American anthropologist White believes there is no sign there would be no culture, no intellectuals will be lost and the difference between animals and humans ceases.

Soft power is a exotic for our country, the term "soft power" was first coined by Harvard professor Joseph Nye "is destined to lead the world: the nature of American power change" His book, he said: "Soft power is a kinds of ability, through attraction rather than coercion can achieve their goals. This attraction comes from a country's culture, political values and foreign policy. "Scholars started mainly on Western scholars view i full release, now has to China in the development paradigm. Yan Xuetong, professor at Tsinghua University, pointed out: "soft power. It is a country's internal and external political mobilization, namely domestic and international mobilization and the use of hard power capabilities. he further noted that the soft power of culture including aspects of universal education, science and technology, literature and art, the press, television movies, clothing and diet. "Relative to Joseph Nye's soft power will be interpreted as 
cultural attractiveness, attractiveness and political values shape international rules and decisions of the political issues of capacity, Chinese scholars have tended to be regarded as cultural soft power core, the soul. Secondly, the Chinese scholars to give a broader definition of soft power that soft power is not just a means of international political game, with the specific reality of our country, soft power is also an important goal of our spiritual and cultural construction, focusing to improve China's comprehensive national strength.

\section{The Importance of Lifting the Lower Context of Globalization Cultural Soft Power}

An important embodiment of the soft power of culture is that it has a strong cohesion, our country is one of many multi-ethnic population, if there is no common national core values and ethos of the inherent people gather together, it is impossible to unite the entire nation, work together to promote economic construction, national defense construction and military construction. Since the reform and opening up, our society has undergone tremendous changes in the market economy, driven by the rapid growth of the material wealth of the country, and spiritual culture is relatively fatigue, the common ideal of people's common values beliefs target gradually blurred, so that the internal country cohesion than socialist revolution's very different. Calmly Chinese modern history can be found in poor physical force is only temporary, the lack of spiritual culture is deadly, precisely because of the poor leadership of the Communist Party of China to achieve common ideals, with the right guidance of Marxism-Leninism, in order to obtain a time of revolutionary struggle in victory, and ultimately people are the masters. Therefore, only by strengthening cultural construction, highlighting our core values through a strong cultural soft power, to promote traditional culture and national spirit, to shape a common vision to enhance our national cohesion, solidarity in order to achieve the united struggle of people of all nationalities together to advance economic, defense, military hard power development.

Hard power to achieve long-term development, we must have the innovation and creativity, these are people with innovative ideas, innovative spirit and ability to achieve, and people's creativity and endless source of culture comes from the running water. Culture is essentially a product of human social practice, or "humanized" thing, it carries the wisdom and cultural achievements of their predecessors; as people practice creative externalization, which in turn acts on the people, that "people-oriented" cultural achievements is the accumulation of increased cognitive ability, innovative ideas so that people can continue to enhance and innovation. Therefore, the level of intelligence and culture to improve the quality of civilization peoples have a fundamental role for the development of cultural soft power, hard power of the country provides a powerful creativity, is an important guarantee for the realization of China's modernization.

In the context of economic globalization, the interests of national development and criss-crossing, China's economic development and political security needs a favorable international environment. Without a favorable international environment, globalization can not be the only platform for favorable economic development, it will become an obstacle, even if development of their own will be questioned, such as the rise in recent years of "China threat theory" has caused some Western countries to China misunderstanding of development in order to take some of the repressive attitude and means in association with China. In this case, improve China's cultural soft power in favor of our country to showcase China's image in the global cultural exchange, the charm of Chinese culture and China, have their own "voice" to eliminate misunderstanding, enhancing our cultural values, ideology, development mode and the national spirit in the world Fu Injection power and charisma for our hard power development provides an important attraction. 
Soft power is non-mandatory national forces, including the various elements of the path of development, system design, political values and ideologies, etc., and these elements are all based on the "culture" based on soft power. Such as those containing the national spirit and core values, including cultural soft power, our peoples can create a strong cohesion and the creation of socialist core values, can provide the mainstream ideology of political domination, improve the social acceptance of people of the country will cohesion and recognition of this non-coercive manner obtained can play in national development in a more far-reaching effects on the broader sense. Therefore, it is the relationship between the whole and the parts and that was the decisive elements of the culture of each other, globalization development process to enhance the soft power of culture is to strengthen our overall national soft power, cultural soft power to China soft power enhancement of decisive significance.

\section{Strategies to Enhance China's Cultural Soft Power}

National Traditional Culture is a certain ethnic heritage in the long years of common life and production, is the nation's "original formation" and common "collective memory" is the national life of the most authoritative patterns of behavior, which, once formed, will become the national intellectual inquiry carried out preconditions, its cultural creativity can not get rid of traditional culture inheritance. Traditional culture is a fundamental national survival, is the nation's "identity card", is the foundation and core of national cultural soft power, is also an important source of national cultural soft power. It is because traditional culture has such an important role in the process of globalization and modernization parallel, our country should actively protect, promote and develop the national traditional culture, enhance people's sense of identity to the Chinese traditional culture, a sense of belonging and pride to play cultural soft power of attraction and cohesion, the people of all nationalities gather together to achieve the great rejuvenation of the Chinese nation.

Innovation is a country, source of national cultural development, rigid, legalistic will eventually lead to elimination of the times. Improving cultural soft power, in addition to consolidating the foundation of survival, to inherit and carry forward the fine traditional culture of our country, absorb the outstanding foreign cultures, but also the need for innovation on the basis of survival, and development, which is more long-term survival sense. Therefore, it must be based on the growing spiritual needs of our people and the tide of globalization, an independent cultural innovation and enhance the culture of innovation, improve the soft power of culture. Cultural innovation is the concept of having a rich content.

Culture is essentially a spiritual product, is an ideology, it must rely on the media base specific text, sound, images, etc. can be reflected, in order to achieve its self from the presence of a non-free formula. Inherent attractiveness cultural soft power, influence, and so must guiding force through the body by means of media and communication channels in order to achieve public information symbols are perceived, accepted and absorbed. Communication carrying sound, image and cultural ideas of a country or region, is the most direct expression of cultural soft power, but also cultural soft power, the most active part. At present, compared with developed countries, spreading the force of our culture far, China has not yet create a world-class media group, it can have an important influence in the international media has not occurred; our culture propagation techniques, means, way compared with the world-class media there is a big gap, such as news of the original rate, first rate, the floor rate to be further strengthened; the low utilization rate of emerging media

technologies and so on. In view of the shortcomings in the dissemination of culture, the reason is a long time since our original cultural institutions can not meet the construction and development of 
contemporary culture and meet new demands, it is necessary to thoroughly implement the Party Central Committee on deepening of the cultural system, to speed up the government function transformation, increase policy support cultural development, establishment of a modern system of cultural transmission, maximize their cultural creativity of the whole society, strengthen propagation force our culture.

\section{Conclusion}

Since its soft power to raise concern, the domestic and foreign scholars on the "soft power", "cultural soft power," the research results are quite good, many of which we should learn from the place, and the soft power of culture has been some improvement, the influence of Chinese culture in the international arena has also been a certain impression. But in recent years with the gradual development of China's economic strength and growth, international and domestic environment has undergone tremendous changes, Therefore, to explore research of cultural soft power must be closely integrated globalization context of the times, a careful analysis of its soft power to culture construction of the impact, both positive and negative impacts. On this basis, we also need to further integrate China's cultural soft power construction deficiencies actually exist, by promoting the transformation of traditional Chinese culture, promote China's culture of innovation, deepen the reform of China's cultural, nurture and practice the socialist core values to enhance our culture viability, innovation, communication ability and leading force in order to achieve a comprehensive upgrade of China's cultural soft power.

\section{Reference:}

[1] Ye Hui. Power of culture - Cultural Perspective Zhejiang Economic and Social Development [J]. Guangming Daily, 2008-06-27.

[2] Bin De. Enduring Road Jiang Lijuan Reader's Digest [J]. China Periodicals Association newsletter, 2002, (2).

[3] Li Lei. cultural industries to enhance the soft power of culture to cultivate. Second National Conference on Cultural Systems Cultural Industries Summary [J]. Guangming Daily, 2008.10.19.

[4] Dong Shijun. Enhance national cultural soft power: content, context and mission [J]. Mao Zedong and Deng Xiaoping Theory, 2008, (4). 